\title{
Prediksi Hasil Panen Kopi Di Sulawesi Menggunakan Analisis Rantai Markov
}

Try Azisah Nurman

Program Studi Matematika FST, UINAM, try.azisah@uin-alauddin.ac.id

Ilham Syata

Program Studi Matematika FST, UINAM, ilham.syata@uin-alauddin.ac.id

Cahaya Dewi Wulandari

Program Studi Matematika-FST,UINAM,60600117027@uin-alauddin.ac.id

\begin{abstract}
ABSTRAK, Penelitian ini membahas tentang prediksi hasil panen kopi di Sulawesi menggunakan analisis rantai markov. Rantai Markov merupakan salah satu teknik analisis yang dapat digunakan untuk memprediksi perubahan dimasa mendatang atas perubahan-perubahan dimasa lalu. Penelitian ini bertujuan untuk mengetahui prediksi hasil panen kopi di Sulawesi pada tahun 2020 sampai tahun 2022 berdasarkan rantai markov. Hasil penelitian ini menyatakan pada tahun 2020 hasil panen kopi di Provinsi Sulawesi Utara sebesar 3,3 ribu ton, Provinsi Sulawesi Tengah sebesar 2,9 ribu ton, Provinsi Sulawesi Selatan sebesar 32,2 ribu ton, Provinsi Gorontalo sebesar 0,4 ribu ton, Provinsi Sulawesi tenggara sebesar 2,6 ribu ton dan Provinsi Sulawesi Barat sebesar 3,4 ribu ton. Pada tahun 2021 hasil panen kopi di Provinsi Sulawesi Utara sebesar 3,4 ribu ton, Provinsi Sulawesi Tengah sebesar 2,8 ribu ton, Provinsi Sulawesi Selatan sebesar 32,2 ribu ton, Provinsi Gorontalo sebesar 0,2 ribu ton, Provinsi Sulawesi tenggara sebesar 2,7 ribu ton dan Provinsi Sulawesi Barat sebesar 3,2 ribu ton. Pada tahun 2022 hasil panen kopi di Provinsi Sulawesi Utara sebesar 3,7 ribu ton, Provinsi Sulawesi Tengah sebesar 2,8 ribu ton, Provinsi Sulawesi Selatan sebesar 34,2 ribu ton, Provinsi Gorontalo sebesar 0,2 ribu ton, Provinsi Sulawesi tenggara sebesar 2,5 ribu ton dan Provinsi Sulawesi Barat sebesar 3,2 ribu ton. Dengan probabilitas steady state hasil panen kopi untuk Sulawesi Utara sebesar 0,0743, Sulawesi Tengan sebesar 0,0656, Sulawesi Selatan sebesar 0,7167, Gorontalo sebesar 0,0091, Sulawesi Tenggara sebesar 0,0582 dan Sulawesi Barat sebesar 0,0761.
\end{abstract}

Kata Kunci: Rantai Markov, Hasil Panen kopi di Sulawesi

\section{PENDAHULUAN}

Tanaman kopi adalah salah satu komoditas ekspor unggulan yang dikembangkan di Indonesia karena memiliki nilai ekonomis yang relatif tinggi di pasaran dunia. Permintaan kopi di Indonesia terus meningkat dari waktu ke waktu. Sebagian besar perusahaan baik milik pemerintah maupun swasta membudidayakan tanaman kopi untuk memenuhi permintaan pasar yang semakin meningkat.

Indonesia termasuk salah satu negara produsen dan eksportir kopi terbesar dunia. Kopi yang dibudidayakan di Indonesia adalah jenis kopi Arabika dan Robusta yang tergolong mempunyai kualitas yang baik sehingga hasil panen kopi tersebut dapat di ekspor ke Negara-negara maju seperti Amerika, Jepang, Belanda, Jerman dan Italia[1].

Sulawesi merupakan salah satu daerah penghasil kopi di Indonesia. Pada tahun 2019 luas perkebunan kopi di Sulawesi mencapai 114 ribu hektar dan pada periode tahun 2011 hingga 2019, Sulawesi Utara menghasilkan kopi sebanyak 26,25 ribu ton, Sulawesi Tengah sebanyak 24,98 ribu ton, Sulawesi Selatan sebanyak 256,85 ribu ton, Sulawesi Tenggara sebanyak 26,5 ribu ton, Gorontalo sebanyak 39,24 ribu ton dan Sulawesi Barat sebanyak 38,27 ribu ton[2]. hasil panen kopi dipengaruhi oleh beberapa faktor, salah satunya adalah jumlah curah hujan. Pemerintah telah melakukan beberapa cara untuk meningkatkan hasil panen kopi, namun kurangnya teknologi dan kurangnya sarana prediksi hasil panen kopi pada pemerintah dan petani menjadi salah satu kendala dalam peningkatan hasil panen kopi.

Jumlah hasil panen dapat diprediksi dengan salah satu teknik matematika yaitu analisis rantai Markov. Rantai Markov merupakan salah satu teknik analisis yang dapat digunakan untuk memprediksi perubahan dimasa mendatang atas perubahan-perubahan dimasa lalu.

Berdasarkan uraian di atas, penelitian ini bertujuan untuk mengetahui prediksi hasil panen kopi di Sulawesi pada tahun 2020 sampai tahun 2022 berdasarkan rantai markov.

\section{TINJAUAN PUSTAKA}

\section{Matriks}

Matriks adalah himpunan bilanganbilangan yang disusun dalam jajaran persegi 
yang dibatasi dengan kurung siku atau kurung biasa. Bilangan-bilangan dalam matriks disebut elemen matriks. Dimana susunan bilangan horizontal disebut baris dan susunan bilangan vertikal disebut kolom. Ukuran atau ordo suatu matriks dapat ditentukan dari jumlah baris (m) dan kolom $(n)$ Ukuran matriks dinyatakan dalam "baris kali kolom" yaitu ( $m$ x $n)$. Matriks dinotasikan dengan huruf kapital, sedangkan elemen matriks menggunakan huruf kecil. Secara umum matriks dapat ditulis dalam bentuk sebagai berikut: [3]

$$
\left[\begin{array}{cccc}
a_{11} & a_{12} & \ldots & a_{1 n} \\
a_{21} & a_{22} & \ldots & a_{2 n} \\
\vdots & \vdots & \vdots & \vdots \\
a_{m 1} & a_{m 2} & \ldots & a_{m n}
\end{array}\right]
$$

\section{Jenis-jenis Matriks}

Jenis-jenis matriks ialah matriks bujur sangkar, matriks diagonal, matriks segitiga (bsegitiga bawah dan segitiga atas), matriks scalar, matriks simetris, matriks baris, matriks kolom[4], matriks nol[5] dan matriks identitas[6].

\section{Operasi Dasar Matriks}

Perkalian matriks: [8]

Penjumlahan dan pengurangan matriks:

$$
c_{i j}=a_{i j} \pm b_{i j}
$$

$$
c_{i j}=\sum_{k=1}^{m} a_{i k} \cdot b_{k j}
$$

\section{Peluang}

\section{Definisi Peluang}

Definisi 2.1:

Peluang dapat diartikan sebagai ukuran yang digunakan untuk mengetahui suatu peristiwa terjadi atau tidak terjadi. Sebuah peristiwa memiliki nilai peluang antara nol dan satu.

\section{Definisi 2.2:}

Nilai probabilitas terkecil adalah 0 yang berarti bahwa suatu peristiwa tidak akan terjadi. Sedangkan nilai probabilitas terbesar adalah 1 yang berarti bahwa suatu peristiwa pasti akan terjadi.[9]

\section{Perumusan Peluang}

Perumusan klasik:

$$
P(A)=\frac{n}{N}
$$

Perumusan Frekuensi Relatif:

$$
P(A)=\lim _{N \rightarrow \infty} \frac{n}{N}
$$

Pendekatan subjektif[10]

\section{Peluang Peristiwa}

Peluang dua peristiwa saling lepas:

$$
\mathrm{P}(\mathrm{A} \cup \mathrm{B})=\mathrm{P}(\mathrm{A})+\mathrm{P}(\mathrm{B})
$$

Peluang dua peristiwa saling bebas:

$$
\mathrm{P}(\mathrm{A} \cap \mathrm{B})=\mathrm{P}(\mathrm{A}) \times \mathrm{P}(\mathrm{B})
$$

\section{Peluang kejadian bersyarat:}

Peluang bersyarat menunjukkan besarnya peluang suatu peristiwa akan terjadi setelah terjadinya peristiwa lain yang independen terhadap peristiwa tersebut.[11]

$$
\mathrm{P}(\mathrm{A} \mid \mathrm{B})=\frac{\mathrm{P}(\mathrm{A} \cap \mathrm{B})}{\mathrm{P}(\mathrm{B})}
$$

\section{Analisis Rantai Markov \\ Proses Stokastik}

Proses stokastik adalah barisan peristiwa yang memenuhi hukum-hukum peluang. Suatu nilai dikatakan mengikuti proses stokastik ketika nilai tersebut berubah terhadap waktu secara acak. Apabila kejadian yang akan datang dapat diprediksi secara pasti berdasarkan pengalaman yang lalu, barisan kejadian tersebut dinamakan deterministik. Kebalikannya, apabila pengalaman yang lalu hanya dapat menyajikan struktur peluang keadaan yang akan datang, maka barisan tersebut dinamakan stokastik.

\section{Pengertian Rantai Markov}

Model rantai Markov dikembangkan oleh A.A Markov pada tahun 1896. Proses analisis rantai Markov mengeluarkan hasil berupa informasi probabilistik yang dapat digunakan untuk membantu pembuatan keputusan, jadi analisis ini bukan suatu teknik optimasi melainkan suatu teknik deskriptif. Analisis markov adalah suatu teknik khusus dari model probabilistik yang dikenal dengan proses stokastik[12].

Untuk mengetahui prediksi peristiwa pada waktu $t_{(j)}$ pada rantai markov dapat menggunakan persamaan berikut:

$$
K_{t(j)}=K_{t(j-1)} P
$$

dimana:

$K_{t(j)}=$ peluang kejadian pada waktu $t_{(j)}$ 
$P \quad=$ probabilitas transisi

$t_{(j-1)}=$ waktu ke- $(j-1)$

$t_{(j)} \quad=$ waktu ke-j[13]

\section{Langkah-langkah Rantai Markov}

Langkah-langkah rantai markov untuk mencari probabilitas pada masa mendatang adalah sebagai berikut:

a. Membuat matriks transisi dari probabilitas yang telah diketahui.

b. Kalikan probabilitas waktu sebelumnya dengan matriks transisi.

c. Lakukan langkah 1 dan 2 sampai menemukan probabilitas yang hendak dicari.[14]

\section{Asumsi-asumsi Rantai Markov}

Dalam analisis antai Markov terdapat beberapa asumsi yaitu:

a. Jumlah probabilitas transisi suatu kejadian adalah 1.

b. Peluang transisi hanya bergantung pada peluang kejadian sekarang dan tidak bergantung pada peluang kejadian masa lalu.

c. Nilai peluang transisi tidak berubah.[15]

\section{Contoh Aplikasi Rantai Markov}

Awalnya rantai markov diterapkan dalam ilmu-ilmu fisika dan meteorology seperti meramalkan cuaca melalui kegiatan analisis terhadap perilaku partikel-partikel gas dalam wadah tertutup. Namun saat ini markov chain banyak diterapkan dalam manajemen industri seperti:

a. Menganalisis perpindahan minat pada merek tertentu (brand switching) dalam pemasaran,

b. Perencanaan pemeliharaan mesin,

c. Perencanaan antrian,

d. Menganalisis perubahan harga pasar saham,

e. Pengelolaan administrasi rumah sakit,

f. Perencanaan persediaan bahan baku dan sebagainya[16].

\section{Probabilitas transisi}

Definisi 2.3:

Jika sebuah rantai Markov mempunyai $k$ kemungkinan keadaan yang ditandai dengan 1, $2, \ldots, k$, maka jika probabilitas sistem berada dalam keadaan $i$ setelah mengalami kejadian $j$ pada pengamatan sebelumnya dilambangkan dengan $p_{i j}$ yang disebut probabilitas transisi dari kejadian $j$ ke $i$. matriks $p=\left[p_{i j}\right]$ dinamakan matriks transisi rantai Markov.[17]

Peluang transisi dapat di hitung menggunakan rumus berikut:

$$
P_{i j}=\frac{n_{i j}(t)}{n_{i}(t)}
$$

Dimana:

$P_{i j} \quad=$ peluang transisi

$n_{i j}(t) \quad=$ nilai dari state $i$ ke state $j$ dalam periode $\mathrm{t}$

$n_{i}(t)=$ nilai state $i$ dalam periode $\mathrm{t}[18]$

\section{Peluang transisi $\boldsymbol{n}$-langkah}

Peluang transisi $n$-langkah $P^{(n)}$ merupakan peluang bersyarat suatu sistem yang berada pada state $i$ akan berada pada state $j$ setelah proses mengalami $n$ transisi, jadi:

$$
P^{(n)}=P^{n}
$$

\section{Persamaan Chapman-kolmogorov}

Persamaan Chapman-kolmogorov dapat digunakan untuk menghitung peluang transisi nlangkah dengan persamaan sebagai berikut: [19]

$$
P_{i j}^{(n+m)}=\sum_{k=1}^{N} P_{i k}^{(n)} P_{k j}^{(m)}
$$

\section{Probabilitas Steady-State}

Probabilitas steady-state merupakan probabilitas transisi dimasa yang akan datang akan tidak bergantung dari keadaan awal. Probabilitas transisi pada tahap keadaan steadystate adalah peluang peralihan yang sudah mencapai keseimbangan sehingga tidak akan berubah terhadap perubahan waktu yang akan terjadi.

Probabilitas steady-state didefinisikan sebagai berikut:[20]

$$
\lim _{n \rightarrow \infty} p_{i j}^{(n)}=\pi_{j}>0
$$

Dimana $\pi_{j}$ harus memenuhi persamaan steadystate yaitu:[21]

$$
\begin{array}{ll}
\text { a. } & \pi_{j}=\sum_{i=0}^{M} \pi_{j} p_{i j} ; \quad j=0,1, \ldots M \\
\text { b. } \sum_{j=0}^{M} \pi_{j}=0
\end{array}
$$

$\pi_{j}$ merupakan probabilitas steady-state dari Markov chain. Perlu dicatat bahwa probabilitas steady-state tidak menunjukkan bahwa proses tersebut menjadi satu langkah. Namun sebaliknya, proses tersebut akan terus melakukan 
transisi dari state ke state dan pada setiap langkah n-probabilitas transisi dari state $i$ ke state $j$ tetap $P_{i j}$.

\section{METODOLOGI}

Adapun prosedur penelitian yang akan dilakukan untuk mengetahui prediksi hasil panen kopi di Sulawesi pada tahun 2020 sampai tahun 2022 adalah sebagai berikut:

1. Membuat matriks probabilitas transisi untuk mendapatkan probabilitas hasil panen kopi masing-masing provinsi di Sulawesi,

2. Menghitung prediksi hasil panen kopi masing-masing provinsi di Sulawesi pada tahun 2020 sampai tahun 2022,

3. Menghitung prediksi probabilitas SteadyState untuk mendapatkan probabilitas keadaan keseimbangan hasil panen kopi masing-masing provinsi di Sulawesi.

\section{PEMBAHASAN}

\section{Membuat matriks probabilitas transisi}

Data dalam penelitian ini adalah data hasil panen kopi di Indonesia dalam rentang waktu enam tahun, dimulai dari tahun 2014 hingga tahun 2019. Berikut merupakan data hasil panen kopi di Sulawesi:

Tabel 4.1 Data jumlah hasil panen kopi di Sulawesi Selatan

\begin{tabular}{cccccccc}
\hline \multirow{2}{*}{ Tahun Hasil panen kopi } & \multicolumn{3}{c}{ (ribu ton) } & \multirow{2}{*}{ Total } \\
\cline { 2 - 7 } & U & T & S & G & Te & B & \\
\hline 2014 & 3 & 3,6 & 30,1 & 2,9 & 1 & 6,4 & 47 \\
2015 & 3 & 3,1 & 30,5 & 0,5 & 3,1 & 1,9 & 42,1 \\
2016 & 3,3 & 2,9 & 31,9 & 0.2 & 2,7 & 3,2 & 44.2 \\
2017 & 3,5 & 2,7 & 33,5 & 0,2 & 2,7 & 3,3 & 45,9 \\
2018 & 3,9 & 2,8 & 34,7 & 0,2 & 2,5 & 3,2 & 47,3 \\
2019 & 3,7 & 2,6 & 34.7 & 0,1 & 2.8 & 4.1 & 48 \\
\hline
\end{tabular}

$\begin{array}{llllllll}\text { Total } & 20,4 & 17.7 & 195,4 & 4,1 & 14,8 & 22,1 & 274,5\end{array}$

$\begin{aligned} & \text { Keterangan: U }: \text { Sulawesi Utara } \\ & \text { T }: \text { Sulawesi Tengah } \\ & \text { S }: \text { Sulawesi Selatan } \\ & \text { G }: \text { Gorontalo } \\ & \text { Te }: \text { Sulawesi Tenggara } \\ & \text { B }: \text { Sulawesi Barat }\end{aligned}$

Pada Tabel 4.1 terlihat bahwa jumlah keseluruhan produksi kopi di Sulawesi pada rentang waktu tahun 2014 hingga 2019 sebesar
274,7 ribu ton, dimana Provinsi Sulawesi Selatan menghasilkan kopi tertinggi dengan total hasil panen sebesar 195,4 ribu ton dan Provinsi Gorontalo memiliki total produksi terendah dengan total hasil panen sebesar 5,8 ribu ton.

Berdasarkan Tabel 4.1 dengan menggunakan persamaan 2.9 diperoleh peluang transisi dan matriks peluang transisi sebagai berikut:

Tabel 4.2 Probabilitas transisi

\begin{tabular}{ccccccc}
\hline \multirow{2}{*}{ Tahun } & \multicolumn{5}{c}{ Provinsi di Sulawesi } \\
\cline { 2 - 7 } & $\mathrm{U}$ & $\mathrm{T}$ & $\mathrm{S}$ & $\mathrm{G}$ & $\mathrm{Te}$ & $\mathrm{B}$ \\
\hline
\end{tabular}

$20140,06380,07660,64040,06170,02130,1362$

$20150,07130,07360,72450,01190,07360,0451$

$20160,07470,06560,72170,00450,06110,0724$

$20170,07630,05880,72980,00440,05880,0719$

$20180,08240,05920,73360,00420,05290,0677$

$\begin{array}{lllllllllllll}2019 & 0,0771 & 0,0542 & 0,7229 & 0,0021 & 0,0583 & 0,0854\end{array}$

Tabel 4.2 menunjukkan bahwa peluang hasil panen kopi di Sulawesi utara, Sulawesi Tengah, Sulawesi Selatan, Gorontalo, Sulawesi Tenggara dan Sulawesi Barat pada tahun 2014 masingmasing sebesar 6,38\%, 7,66\%, 64,04\%, 6,17\%, 2,13\% dan 13,62\%. Pada tahun 2015 masingmasing sebesar $7,13 \%, 7,36 \%, 72,45 \%, 1,19 \%$, 7,36\% dan 4,51\%. Pada tahun 2016 masingmasing sebesar $7,47 \%, 6,56 \%, 72,17 \%, 0,45 \%$, $6,11 \%$ dan 7,24\%. Pada tahun 2017 masingmasing sebesar 7,63\%, 5,88\%, 72,98\%, 0,44\%, $5,88 \%$ dan 7,19\%. Pada tahun 2018 masingmasing sebesar 8,24\%, 5,92\%, 73,36\%, 0,42\%, $5,29 \%$ dan 6,77\%. Pada tahun 2019 masingmasing sebesar 7,71\%, 5,51\%, 72,29\%, 0,21\%, $5,83 \%$ dan $8,54 \%$.

Berdasarkan nilai yang diperoleh pada Tabel 4.2 matriks probabilitas jumlah produksi kopi yang terbentuk adalah sebagai berikut:

$P_{i j}=\left[\begin{array}{llllll}0,0638 & 0,0766 & 0,6404 & 0,0617 & 0,0213 & 0,1362 \\ 0,0713 & 0,0736 & 0,7245 & 0,0119 & 0.0736 & 0,0451 \\ 0,0747 & 0,0656 & 0,7217 & 0,0045 & 0,0611 & 0,0724 \\ 0,0763 & 0,0588 & 0,7298 & 0,0044 & 0,0588 & 0,0719 \\ 0,0824 & 0,0592 & 0,7336 & 0,0042 & 0,0529 & 0,0677 \\ 0,0771 & 0,0542 & 0,7229 & 0,0021 & 0,0583 & 0,0854\end{array}\right]$

\section{Menghitung prediksi hasil panen dimasa mendatang}

Hal pertama yang dilakukan untuk menghitung prediksi hasil panen kopi dimasa mendatang yaitu menghitung probabilitasnya. 
Hal pertama yang dilakukan ntuk menghitung prediksi hasil panen kopi dimasa mendatang yaitu menghitung probabilitasnya. Cara untuk menghitung probabilitas pada tahun pertama $\pi(1)$ yaitu tahun 2020 dilakukan dengan cara mengalikan vektor initial state $\pi(0)$ dengan matriks probabilitas, dimana $\pi(0)$ merupakan jenis state yang dilambangkan dengan bilangan binear 0 atau 1. Dalam penelitian ini, peneliti menggunakan initial state sebagai berikut:
$\pi(0)=\left[\begin{array}{llllll}1 & 0 & 0 & 0 & 0 & 0\end{array}\right]$

1. Prediksi hasil panen kopi tahun 2020 (P2020)

a. Probabilitas hasil panen kopi tahun 2020

$$
\begin{aligned}
\pi(1) & =\left[\begin{array}{lllllll}
1 & 0 & 0 & 0 & 0 & 0
\end{array}\right] \times\left[\begin{array}{lllllll}
0,0638 & 0,0766 & 0,6404 & 0,0617 & 0,0213 & 0,1362 \\
0,0713 & 0,0736 & 0,7245 & 0,0119 & 0,0736 & 0,0451 \\
0,0747 & 0,0656 & 0,7217 & 0,0045 & 0,0611 & 0,0724 \\
0,0763 & 0,0588 & 0,7298 & 0,0044 & 0,0588 & 0,0719 \\
0,0824 & 0,0592 & 0,7336 & 0,0042 & 0,0529 & 0,0677 \\
0,0771 & 0,0542 & 0,7229 & 0,0021 & 0,0583 & 0,0854
\end{array}\right] \\
& =\left[\begin{array}{lllllll}
0,0638 & 0,0766 & 0,6404 & 0,0617 & 0,0213 & 0,1362
\end{array}\right]
\end{aligned}
$$

b. Prediksi hasil panen kopi tahun 2020:

$$
\begin{aligned}
\mathrm{P} 2020= & {[0,0638} \\
& \times\left[\begin{array}{cccccc}
3 & 3,6 & 30,1 & 2,9 & 1 & 6,4 \\
3 & 3,1 & 30,5 & 0,5 & 3,1 & 1,9 \\
3,3 & 2,9 & 31,9 & 0,2 & 2,7 & 3,2 \\
3,5 & 2,7 & 33,5 & 0,2 & 2,7 & 3,3 \\
3,9 & 2,8 & 34,7 & 0,2 & 2,5 & 3,2 \\
3,7 & 2,6 & 34,7 & 0,1 & 2,8 & 4,1
\end{array}\right] \\
& =\left[\begin{array}{lllllll}
3,3 & 2,9 & 32,2 & 0,4 & 2,6 & 3,4
\end{array}\right]
\end{aligned}
$$

2. Prediksi hasil panen kopi tahun 2021 (P2021)

a. Probabilitas hasil panen kopi tahun 2021

$$
\begin{aligned}
& \pi(2)=\left[\begin{array}{llllll}
0,0638 & 0,0766 & 0,6404 & 0,0617 & 0,0213 & 0,1362
\end{array}\right] \\
& \times\left[\begin{array}{llllll}
0,0638 & 0,0766 & 0,6404 & 0,0617 & 0,0213 & 0,1362 \\
0,0713 & 0,0736 & 0,7245 & 0,0119 & 0.0736 & 0,0451 \\
0,0747 & 0,0656 & 0,7217 & 0,0045 & 0,0611 & 0,0724 \\
0,0763 & 0,0588 & 0,7298 & 0,0044 & 0,0588 & 0,0719 \\
0,0824 & 0,0592 & 0,7336 & 0,0042 & 0,0529 & 0,0677 \\
0,0771 & 0,0542 & 0,7229 & 0,0021 & 0,0583 & 0,0854
\end{array}\right] \\
& =\left[\begin{array}{llllll}
0,07433 & 0,06481 & 0,71764 & 0,00838 & 0,05882 & 0,07602
\end{array}\right]
\end{aligned}
$$


b. Prediksi hasil panen kopi tahun 2021:

$$
\begin{aligned}
& \mathrm{P} 2021=\left[\begin{array}{llllll}
0,07433 & 0,06481 & 0,71764 & 0,00838 & 0,05882 & 0,07602
\end{array}\right] \\
& \times\left[\begin{array}{cccccc}
3 & 3,1 & 30,5 & 0,5 & 3,1 & 1,9 \\
3,3 & 2,9 & 31,9 & 0,2 & 2,7 & 3,2 \\
3,5 & 2,7 & 33,5 & 0,2 & 2,7 & 3,3 \\
3,9 & 2,8 & 34,7 & 0,2 & 2,5 & 3,2 \\
3,7 & 2,6 & 34,7 & 0,1 & 2,8 & 4,1 \\
3,3 & 2,9 & 32,2 & 0,4 & 2,6 & 3,4
\end{array}\right] \\
& =\left[\begin{array}{llllll}
3,4 & 2,8 & 33,2 & 0,2 & 2,7 & 3,2
\end{array}\right]
\end{aligned}
$$

3. Prediksi hasil panen kopi tahun 2022 (P2022)

a. Probabilitas hasil panen kopi tahun 2022

$$
\begin{aligned}
& \pi(3)=\left[\begin{array}{llllll}
0,07433 & 0,06481 & 0,71764 & 0,00838 & 0,05882 & 0,07602
\end{array}\right. \\
& \times\left[\begin{array}{llllll}
0,0638 & 0,0766 & 0,6404 & 0,0617 & 0,0213 & 0,1362 \\
0,0713 & 0,0736 & 0,7245 & 0,0119 & 0.0736 & 0,0451 \\
0,0747 & 0,0656 & 0,7217 & 0,0045 & 0,0611 & 0,0724 \\
0,0763 & 0,0588 & 0,7298 & 0,0044 & 0,0588 & 0,0719 \\
0,0824 & 0,0592 & 0,7336 & 0,0042 & 0,0529 & 0,0677 \\
0,0771 & 0,0542 & 0,7229 & 0,0021 & 0,0583 & 0,0854
\end{array}\right] \\
& =\left[\begin{array}{llllll}
0,07432 & 0,06564 & 0,71669 & 0,00903 & 0,05824 & 0,07608
\end{array}\right]
\end{aligned}
$$

b. Prediksi hasil panen kopi di Sulawesi tahun 2022:

$$
\begin{aligned}
& \text { P2022 }=\left[\begin{array}{lllllll}
0,07432 & 0,06564 & 0,71669 & 0,00903 & 0,05824 & 0,07608
\end{array}\right] \\
& \times\left[\begin{array}{llllllll}
3,3 & 2,9 & 31,9 & 0,2 & 2,7 & 3,2 \\
3,5 & 2,7 & 33,5 & 0,2 & 2,7 & 3,3 \\
3,9 & 2,8 & 34,7 & 0,2 & 2,5 & 3,2 \\
3,7 & 2,6 & 34,7 & 0,1 & 2,8 & 4,1 \\
3,3 & 2,9 & 32,2 & 0,4 & 2,6 & 3,4 \\
3,4 & 2,8 & 33,2 & 0,2 & 2,7 & 3,2
\end{array}\right] \\
&= {\left[\begin{array}{llllllll}
3,7 & 2,8 & 34,2 & 0,2 & 2,5 & 3,2
\end{array}\right] }
\end{aligned}
$$

Secara ringkas hasil prediksi ditampilkan dalam tabel berikut:

Tabel 4.3 Prediksi hasil panen kopi (ribu ton)

\begin{tabular}{ccccccc}
\hline Tahun & $\mathrm{U}$ & $\mathrm{T}$ & $\mathrm{S}$ & $\mathrm{G}$ & $\mathrm{Te}$ & $\mathrm{B}$ \\
\hline 2020 & 3,3 & 2,9 & 32,2 & 0,4 & 2,6 & 3,4 \\
2021 & 3,4 & 2,8 & 33,2 & 0,2 & 2,7 & 3,2 \\
2022 & 3,7 & 2,8 & 34,2 & 0,2 & 2,5 & 3,2 \\
\hline
\end{tabular}

Tabel 4.3 menunjukkan bahwa pada tahun 2020 hasil panen kopi di Provinsi Sulawesi Utara sebesar 3,3 ribu ton, Provinsi Sulawesi Tengah sebesar 2,9 ribu ton, Provinsi Sulawesi Selatan sebesar 32,2 ribu ton, Provinsi Gorontalo sebesar 0,4 ribu ton, Provinsi Sulawesi tenggara sebesar 2,6 ribu ton dan Provinsi Sulawesi Barat sebesar
3,4 ribu ton. Pada tahun 2021 hasil panen kopi di Provinsi Sulawesi Utara sebesar 3,4 ribu ton, Provinsi Sulawesi Tengah sebesar 2,8 ribu ton, Provinsi Sulawesi Selatan sebesar 33,2 ribu ton, Provinsi Gorontalo sebesar 0,2 ribu ton, Provinsi Sulawesi tenggara sebesar 2,7 ribu ton dan Provinsi Sulawesi Barat sebesar 3,2 ribu ton. Pada tahun 2022 hasil panen kopi di Provinsi Sulawesi Utara sebesar 3,7 ribu ton, Provinsi Sulawesi Tengah sebesar 2,8 ribu ton, Provinsi Sulawesi Selatan sebesar 34,2 ribu ton, Provinsi Gorontalo sebesar 0,2 ribu ton, Provinsi Sulawesi tenggara sebesar 2,5 ribu ton dan Provinsi Sulawesi Barat sebesar 3,2 ribu ton. 


\section{Menghitung Probabilitas Steady State}

Prediksi probabilitas steady state diperoleh dengan cara melakukan iterasi probabilitas transisi $n$-langkah hingga mencapai kondisi seimbang, yaitu apabila matriks probabilitas selanjutnya tidak bergantung pada matriks probabilitas transisi sebelumnya. Dengan menggunakan persamaan 2.10 diperoleh bahwa probabilitas terjadi pada $n$-langkah yang ke-7 $\left(P^{7}\right)$, karena pada $n$-langkah yang ke-7 konvergen dengan $n$-langkah sebelumnya dengan probabilitas steady state sebagai berikut:

Tabel 4.4 Probabilitas hasil panen kopi

\begin{tabular}{ccccccc}
\hline Tahun & $\mathrm{U}$ & $\mathrm{T}$ & $\mathrm{S}$ & $\mathrm{G}$ & $\mathrm{Te}$ & $\mathrm{B}$ \\
\hline 2026 & 0.0743 & 0.0656 & 0.7167 & 0.0091 & 0.0582 & 0.0761 \\
\hline
\end{tabular}

Tabel 4.4 menunjukkan bahwa probabilitas steady state hasil panen kopi di Sulawesi diprediksi akan terjadi pada tahun 2026 dengan nilai probabilitas steady state untuk Provinsi Sulawesi Utara sebesar 0,0743, Sulawesi Tengan sebesar 0,0656, Provinsi Sulawesi Selatan sebesar 0,7167, Provinsi Gorontalo sebesar 0,0091, Provinsi Sulawesi Tenggara sebesar 0,0582 dan Provinsi Sulawesi Barat sebesar 0,0761 .

\section{KESIMPULAN}

Berdasarkan hasil analisis rantai markov dari data hasil panen kopi di Sulawesi tahun 2014 hingga 2019 diperoleh kesimpulan bahwa prediksi hasil panen kopi pada tahun 2020 hasil panen kopi di Provinsi Sulawesi Utara sebesar 3,3 ribu ton, Provinsi Sulawesi Tengah sebesar 2,9 ribu ton, Provinsi Sulawesi Selatan sebesar 32,2 ribu ton, Provinsi Gorontalo sebesar 0,4 ribu ton, Provinsi Sulawesi tenggara sebesar 2,6 ribu ton dan Provinsi Sulawesi Barat sebesar 3,4 ribu ton. Pada tahun 2021 hasil panen kopi di Provinsi Sulawesi Utara sebesar 3,4 ribu ton, Provinsi Sulawesi Tengah sebesar 2,8 ribu ton, Provinsi Sulawesi Selatan sebesar 33,2 ribu ton, Provinsi Gorontalo sebesar 0,2 ribu ton, Provinsi Sulawesi tenggara sebesar 2,7 ribu ton dan Provinsi Sulawesi Barat sebesar 3,2 ribu ton. Pada tahun 2022 hasil panen kopi di Provinsi Sulawesi Utara sebesar 3,7 ribu ton, Provinsi Sulawesi Tengah sebesar 2,8 ribu ton, Provinsi Sulawesi Selatan sebesar 34,2 ribu ton, Provinsi Gorontalo sebesar
0,21 ribu ton, Provinsi Sulawesi tenggara sebesar 2,5 ribu ton dan Provinsi Sulawesi Barat sebesar 3,2 ribu ton. Dengan probabilitas steady state untuk Sulawesi Utara sebesar 0,0743, Sulawesi Tengan sebesar 0,0656, Sulawesi Selatan sebesar 0,7167, Gorontalo sebesar 0,0091, Sulawesi Tenggara sebesar 0,0582 dan Sulawesi Barat sebesar 0,0761 .

\section{DAFTAR PUSTAKA}

[1] Kahpi, A. (2017). Budidaya dan produksi kopi di Sulawesi bagian selatan pada abad ke-19. Lensa Budaya: Jurnal Ilmiah IlmuIlmu Budaya, 12(1).

[2] Badan Pusat Statistik. Luas tanaman perkebunan menurut provinsi (ribu hektar), 2011-2019

(https://www.bps.go.id/indicator/ 54/131/1/luas-tanaman-perkebunanmenurut-provinsi.html diakses: 20 april 2020)

[3] Gella, N. J. M., \& Bien, Y. I. (2020). Aljabar Linear Dasar Berbasis IT (Scilab, Geogebra Dan Microsoft Mathematics). Deepublish.

[4] Rifa'i, R. (2016). Aljabar Matriks Dasar. Deepublish.

[5] Andari, A. (2017). Aljabar linear elementer. Universitas Brawijaya Press.

[6] Indriati, K. (2019). Matriks, Vektor, Dan Program Linier. Penerbit Unika Atma Jaya Jakarta.

[7] Saputra, A. (2020). Komputasi untuk teknik kimia menggunakan matlab. Andri Saputra.

[8] Kartika, H. (2017). Aljabar Matrik: Teori dan Aplikasinya dengan Scilab. Deepublish.

[9] Baco, E., Sauddin, A., \& Bakri, N. ANALISIS PERSAINGAN INDUSTRI TELEVISI BERBAYAR MENGGUNAKAN RANTAI MARKOV (STUDI KASUS: PT. INDONUSA TELEMEDIA (TRANSVISION) VERSUS TELEVISI BERBAYAR LAINNYA DI KOTA MAKASSAR TAHUN 2017). Jurnal MSA (Matematika dan Statistika serta Aplikasinya), 7(1), 1827. 
[10] Sudaryono. (2012). Statistika probabilitas (Teori \& Aplikasi). C.V ANDI OFFSET

[11] Nugroho, S. (2008). Dasar Dasar Metode Statistika. Grasindo.

[12] Marli, Z., Rusdiana, S., Rahayu, L., \& Fradinata, E. (2018). PENGANTAR BIOSTATISTIKA DAN APLIKASINYA PADA STATUS KESEHATAN GIZI REMAJA. Syiah Kuala University Press.

[13] Siswanto. (2007). Operation research jilid II. Jakarta: Erlangga

[14] Suhartono, Derwin. Markov chain. (https://socs.binus.ac.id/2013/06/markovchain/ diakses: 30 agustus 2020)

[15] Noeryanti, N., Setyawan, Y., \& Hadinagara, H. (2019). MEMPREDIKSI KEMISKINAN DI PROVINSI DAERAH ISTIMEWA YOGYAKARTA MENGGUNAKAN METODE ANALISIS RANTAI MARKOV. Jurnal Teknologi, 12(1), 45-53.

[16] Rahma, Nidaur. Pengertian markov chain dan contoh pengaplikasiannya. (https:// www.pengadaanbarang.co.id/2020/10/pen gertian-markov-chain-dancontoh.html?m=1 diakses: 18 februari 2021)

[17] Anton, Howard dan Cris Romes. (2005). Aljabar linear elementer versi aplikasi edisi delapan jilid 2. alih bahasa: Irzam Harmein, Julian Gressando. Jakarta: Erlangga

[18] Anton, Howard. (2005). Aljabar Linear Elementer Edisi kedelapan. Jakarta: Erlangga

[19] Ghosh, J. K. (2012). Introduction to Modeling and Analysis of Stochastic Systems, Second Edition by V. G. Kulkarni. International Statistical Review, 80(3), 487-487. https://doi.org/10.1111/j.17515823.2012.00196_19.x

[20] Rizanti, I. N. (2017). Prediksi produksi kayu bundar kabupaten malang dengan menggunakan metode markov chains (Doctoral dissertation, Institut Teknologi Sepuluh Nopember Surabaya).

[21] Hillier, F. S., Gerald, J. L., \& Mark, H. Introduction to Operations Research 1990 6 New York, NY. 